REGULAR ARTICLE

\title{
EFFECT OF PHYSIOLOGICAL AGE OF STEM AND IBA TREATMENT ON ROOTING OF BRANCH CUTTINGS OF TAXUS BACCATA L.
}

\author{
SAUMITRO DAS ${ }^{*}$, L. K. JHA²
}

\author{
${ }^{1}$ Karimganj Forest Division (Territorial), Karimganj 788712, Assam, India
}

${ }^{2}$ Department of Environmental Studies, North-Eastern Hill University, Shillong 793022, Meghalaya, India

\begin{abstract}
The natural population of Taxus baccata L. (Himalayan Yew) throughout the Indian Himalayan Region is greatly reduced due to its extensive and reckless exploitation for "Taxol" an anticancer drug. The effects of overexploitation are exacerbated by the species poor regeneration process, slow growth rate and prolonged seed dormancy. Therefore vegetative propagation by branch cuttings seems to be only practical solution for its large scale multiplication. A study was conducted on six candidate trees (CTs) to examine the effect genotype, physiological age of stem, IBA treatment on rooting of Taxus baccata cuttings. Results revealed that rooting behaviour of cuttings was significantly affected by all the factors under study. Among the six CTs studied, CT 2 (from BSI, Shillong) had given the highest rooting response (46.28\%). The juvenile cuttings have the higher rooting capacity; however the callusing was more prominent in mature cutting. The influence of IBA treatment was also significant for rooting where 1000 was most effective for stimulating rooting juvenile cuttings and $2000 \mathrm{ppm}$ in mature cuttings.
\end{abstract}

Keywords: Branch cuttings, Indole-3-butyric acid, Taxol, Taxus baccata, Vegetative propagation.

\section{INTRODUCTION}

Taxus baccata L. (Himalayan Yew) is an important high altitude medicinal plant species that found in subtropical and temperate region of Himalaya at an altitude between 1800 and $3300 \mathrm{~m}$ amsl [1]. It is a long lived conifer species belonging to family Taxaceae and has immense ethnobotanical importance in Indian Himalayan Region [2]. Traditionally, the extract derived from the bark and leaves is used to cure various ailments like bronchitis, asthma, poisonous insect bites and also acts as an aphrodiasic [3]. However the species is globally known for 'Taxol' a mitotic spindle inhibitor extracted from its leaves and barks. This compound is used in the treatment of patients with lung, breast and ovarian cancer [4]. The extraction of taxol is economically unfeasible and biological unsustainable as only 0.01 to $0.03 \%$ of the dry phloem weight is taxol, against the requirement of a minimum of 2 gms of purified taxol for full regimen of anti-cancer treatment [5]. Despite soaring prices, the demand for this drug is growing at an annual rate of $20 \%$. The global demand of taxol is $800-1000 \mathrm{~kg}$ annual [6]. In India, its annual demand was estimated at 500 tonnes [7].

Due to the huge demand of taxol, Taxus baccata is being exploited by the collectors, traders and industrialists recklessly beyond its regeneration capacity rendering it to the status of endangered species. The species which was earlier found abundant in the Himalayan region are now restricted to few places that have suitable microclimate. Meghalaya, India was once home to very good population of Taxus baccata, but due to rapid destruction of its natural habitat, the species has now become rare and found only in sacred groves and nursery of government owned forest departments.

Due to growing concern on sustainable use and survival of Taxus sp., domestication programmes have been initiated in many places in India where Taxus grows naturally. The challenge, however, is that it is very difficult to regenerate naturally through seeds as it requires complex treatment like in vitro culture and precocious germination [8,9]. So, major focus has been paid on vegetative propagation by branch cuttings to augment its natural regeneration Taxus species is reported as plant with relative potential of regeneration by adventitious rooting of cuttings [10]. Unlike other Taxus species, Taxus baccata is difficult to root and requires longer time [11]. The workers from states in Central Himalayan Region viz. Jammu and Kashmir, Himachal Pradesh and Uttarakhand have developed and standardised the cutting propagation protocol for their respective region [12, 13,14 and 15] The protocols that have been developed in Central Himalayan regions are area specific; and so are suitable there only. The vegetative propagation technique of Taxus baccata for subtropical region of Meghalaya particularly yet to be standardised.

Propagation by cuttings is the most commonly used

\section{Received 17 November 2017; Accepted 10 January 2018 \\ *Corresponding Author}

\section{Saumitro Das}

Karimganj Forest Division (Territorial), Karimganj 788712, Assam, India

Email: suman.envt@gmail.com

(C) This article is open access and licensed under the terms of the Creative Commons Attribution License (http://creativecommons.org/licenses/by/4.o/) which permits unrestricted, use, distribution and reproduction in any medium, or format for any purpose, even commercially provided the work is properly cited. Attribution - You must give appropriate credit, provide a link to the license, and indicate if changes were made. 
method to propagate numerous woody species as it give faster growth rate, greater stock stand uniformity, better site matching and true-to type planting material. Successful propagation of trees by rooting of cuttings depends on many factors such as physiological age of cutting, the propagation environment and the concentration of applied auxin [16, 17 and 18]. Among auxin, generally Indole-3-butyric acid are reported to have better rooting because of its long retention time at the site of the application and is effective in promoting rooting of a large number of tree species [19]. However, the effectiveness of auxin is determined by sensitivity of tissue of cuttings. This sensitivity of tissue is somewhat associated with genetic characteristics of stock plants [20]. So it is necessary to select out best individual tree having better rootabilty prior to propagation program.

In view of this, a rooting trial was conducted to evaluate the rooting potential of two types of cuttings obtained from different candidate trees of Taxus baccata $\mathrm{L}$. with application of IBA.

\section{MATERIALS AND METHODS}

\section{Experimental site}

The rooting trial was conducted in experimental garden of Department of Environmental Studies, North-Eastern Hill University, located at Shillong in Meghalaya, India ( $91^{\circ} 53^{\prime} \mathrm{E}$; $25^{\circ} 36^{\prime} \mathrm{N}$ and $1426 \mathrm{~m} \mathrm{~m}$ amsl). Six candidate trees (CTs) of age group of 10-15 y growing at six different location in East Khasi Hills were identified and tagged as CT 1, CT 2, CT 3, CT 4, CT 5 and CT 6. (The geographic coordinates of location of CTs are given in table 1) The experiment was conducted in a completely randomized block design and a total of 720 cuttings were used ( $n=720 ; 3$ replications $\mathrm{x} 5$ cuttings $\mathrm{x} 6$ CTs $\mathrm{x} 2$ types of cuttings $\mathrm{x} 4$ IBA concentration including control). The study period was between April to October 2012.

\section{Collection and preparation of cuttings}

The collection of branches was made during last week of April. The branches were procured from each CT and brought to the departmental laboratory in moist polythene bag to avoid desiccation. The branches so collected were made into cuttings of $15-20 \mathrm{~cm}$ in length and 0.3 to $1 \mathrm{~cm}$ in diameter. The needles at the basal portion of $2 \mathrm{~cm}$ were stripped off. Finally cuttings were categorised into two groups according to the physiological nature of stem. The cutting with diameter is between $0.3-0.5 \mathrm{~cm}$ and green or light brown colour was classified as 'Juvenile cutting'. 'Mature cutting' was taken as cutting with more than 0.5 $\mathrm{cm}$ but less than $1.0 \mathrm{~cm}$ and dark brown or grey in colour.

\section{IBA treatment and planting}

Four IBA concentrations was tested i.e., control (o ppm), $1000 \mathrm{ppm}, 2000 \mathrm{ppm}$ and $5000 \mathrm{ppm}$. For control treatment, only distilled water was used. The cuttings were soaked at basal $2 \mathrm{~cm}$ with prepared IBA solutions for few seconds and allowed to dry for $15 \mathrm{~min}$. The treated cuttings were planted in perforated polypot $(18 \mathrm{~cm}$ deep and $6.5 \mathrm{~cm}$ diameter) filled with rooting medium containing equal proportions of soil, sand and FYM. Finally the planted polypots were placed in polyhouse and water regularly according to weather condition and moisture status of rooting medium.

\section{Observation recording and data analysis}

The cuttings were assessed for following parameters after six months of planting: number of cuttings rooted (rooting percentage), a number of cutting callused (Callusing percentage), mean number of roots formed per cutting and mean root length. Analysis of variance (ANOVA) was carried out for all the parameters and Least Significant Difference (LSD) test at $5 \%$ probability was used to compare significantly different means using GLM procedure in the SPSS (Statistical Package for Social Sciences version 16). To ensure normality and variance homogeneity, the survival and rooting percentage data were converted into arc sine sqrt $((x+0.5) / 100)$, and data of root number was transformed into square root $(\mathrm{x}+0.5)$ [21].

\section{RESULTS}

The data on all the rooting parameters evaluated are furnished in table 2 to table 5 .

Perusal of the data in table 2 and 3 , rooting and callusing of Taxus baccata was significantly influenced by CT and IBA concentration. Among six CTs, highest rooting (46.28\%) and callusing percentage $(62.50 \%)$ was observed in the cuttings made from CT 2. Owing to highest rooting percentage, CT 2 exhibited maximum number of roots per cutting (3.33 no.) and longest root $(2.43 \mathrm{~cm})$ (fig. 1(c) and 1(d)). Cuttings from CT 1 and CT 3 showed moderate rooting response where their rooting percentage was recorded as 22.23 and $26.06 \%$ respectively. The poor rooting response was observed in cuttings from CT 4 , CT 5 and CT 6 where their mean value of rooting and callusing percentage was less than 10.84\%. Data analysis (table 2) reveals that physiological age of cuttings on rooting percentage was statistically insignificant. However unlike rooting, rate of callusing of cutting was significantly affected by age of cutting where mature cutting exhibited more callusing than juvenile ones (30.56\% vs 25.28\%) (table 3). Different IBA concentration also resulted in differential rate of rooting (table 2 and fig. 1(e) and 1 (f)). The highest rooting for IBA treatment was achieved with concentration of $2000 \mathrm{ppm}$ and $1000 \mathrm{ppm}$ with overall mean percentage was $18.89 \%$ and $18.15 \%$ respectively.

The rooting behaviour of juvenile and mature cutting varied among CTs as interactive effect of CT and physiological age of cutting found to be significant for rooting percentage, root number and root length (table 2, 4 and 5). The juvenile cuttings from CT 2 exhibited overall highest rooting success (51.67\%) followed by the mature cuttings from CT $3(43.33 \%)$ and CT 2 (38.33\%). The root proliferation was prominent in CT 3 (fig. 1(b) and table 4 and 5), where mature cuttings exhibited maximum value for mean root number (5.26 no. s) and mean root length $(2.89 \mathrm{~cm})$. The study also showed that juvenile and mature cuttings responded differently to different concentrations of IBA. Juvenile cutting showed maximum rooting at concentration of $1000 \mathrm{ppm}$ where mean rooting success was recorded as $25.56 \%$ whereas rooting of mature cutting was highest in 2000 ppm with $22.22 \%$ mean rooting.

Rooting and callusing of two types of cutting varied with candidate tree and IBA treatment. The best rooting performance were seen in CT 2 and CT 3 as responded better to IBA treatment than rest the CTs. Juvenile cuttings from CT 2 treated with 1000 IBA had induced overall highest rooting success $(73.33 \%)$. From same tree mature cuttings yielded maximum rooting percentage of $53.33 \%$ at 2000 ppm IBA. The mature cuttings showed best result in CT 3 where IBA treatment at 1000 and 2000 ppm resulted in 53.33\% rooting success. The rate of callusing was highest in CT 2 (62.50\%), where 1000 ppm IBA treated juvenile cuttings scored highest callusing 
percentage (80.00\%) followed by 2000 ppm IBA treated mature cuttings (73.33\%). Mature cuttings from CT 3 (fig. 1(b)) also exhibited better callusing rate (73.33\%) at higher concentration of IBA i.e.2000 and $5000 \mathrm{ppm}$.

\section{DISCUSSION}

CT 2 (Botanical Survey of India, Shillong) represents the best genotype for cutting propagation of Taxus baccata. For rooting of mature cuttings, CT 3 is best candidate tree. Variation in rooting ability of among individual of Taxus baccata as revealed from the present investigation may be controlled by genetic makeup of the donor plant or may be caused by plant environmental factors. It is well known that different species varies in rooting ability, but differences in rooting potential of plant between provenances and individual trees (clones) within species were also reported in many species such as Triplochiton scleroxylon [22], Calliandra calothyrus [23], Dalbergia sisoo [24] and Tectona grandis [25]. According to Ahuja and Libby, genotypes-environmental interaction causes specific changes in the biology and chemistry of the clone, that affects the rooting of clone [26]. In addition to this, microclimate where the clones grow influences the accumulation of carbohydrates within stem tissue also varies from year to year which cause variation in rooting [27 and 28].

Rooting and callusing of Taxus baccata branch cutting was also affected by physiological age of stem. Though, mature cuttings showed low root production than juvenile cuttings, it exhibited more callusing than latter. Similar result was also reported in Dalbergia melanoxylon by Amri et al. (2010) where juvenile cuttings recorded higher rooting percentage and mature cuttings showed higher rate of callus formation [29]. Poor rooting performance of physiological old cuttings can be attributed to accumulation of inhibitory substances, decreased rate of photosynthesis, low endogenous auxin content and altered carbohydrate metabolism [30 and 31]. In present, experiment callus formation somewhat caused delay in root initiation resulting in low rooting percentage in mature cuttings. Das and Jha (2014) found that hardwood cuttings of Taxus wallichiana took considerably longer time than softwood to root [32].

Application of IBA improved rooting performance in Taxus baccta cuttings. But the relative response towards a particular growth regulator varied with place, clone, and age of cuttings and donor plant [30]. The interaction between IBA and CT in the present experiment indicates that not all CT responded in the same way to the IBA treatment. Similar results were reported in Dianthus caryophyllus by Purnachandra et al. (2017) where genotype of plants resulted in differential IBA effect on rooting [33].

Increasing IBA concentration resulted in increased rooting in cuttings but within a certain range as it was observed in CT 1 and CT 2 where the maximum rooting was recorded in 1000-2000 ppm IBA. In addition, interaction between IBA and type of stem also suggests that consideration of the tissue sensitivity in relation to plant growth regulators. Juvenile cuttings being younger than mature cutting require optimally low concentration of IBA (1000 ppm) for root initiation whereas rooting performance of mature cuttings can be improved by optimally higher concentration of IBA as seen in CT 3 where greater rooting percentage was obtained with 2000 and 5000 ppm.

\section{CONCLUSION}

The present study reveals that rooting capacity of Taxus baccata branch cutting was strongly influenced by genotypes. So it is necessary to select appropriate individual (CT) with good rooting potential propagation programme. Candidate Tree 2 can be served as donor plant for cutting in that part of the state. In addition, physiological age of stem and IBA concentration in relation to particular individual should be also taken into account. The lower concentration of IBA at $1000 \mathrm{ppm}$ for juvenile cutting and higher concentration at 2000 ppm for mature cutting could be best combination for vegetative propagation of Taxus baccata. It is hoped that findings of present study will be helpful for developing propagation protocol of Taxus baccata L. especially for subtropical region of Meghalaya.

\section{ACKNOWLEDGEMENT}

We thank Dr. A. A. Mao, Scientist E and In charge, Botanical Survey of India, ERC, Shillong, Meghalaya and State Forest officials of Meghalaya for providing planting materials for research work. The financial assistance to Saumitro Das in the form of UGC NET fellowship from University Grants Commission (UGC), New Delhi, is gratefully acknowledged.

Table 1: Geographical coordinates of region candidate trees were selected

\begin{tabular}{|c|c|c|c|}
\hline Candidate tree (CT) & Place & Latitude & Longitude \\
\hline CT 1 & North Eastern Hill University (NEHU). Mawkynroh Umsing & $25^{\circ} 36^{\prime} 43.55^{\prime \prime} \mathrm{N}$ & $91^{\circ} 533^{\prime} 51.77^{\prime \prime E}$ \\
\hline CT 2 & Botanical Survey of India, Shillong & $25^{\circ} 34^{\prime} 45 \cdot 50^{\prime \prime} \mathrm{N}$ & $91^{\circ} 53^{\prime} 55 \cdot 37^{\prime \prime} \mathrm{E}$ \\
\hline CT 3 & Forest Beat Office, $4^{1 / 2}$ miles, Upper Shillong & $25^{\circ} 32^{\prime} 49.57^{\prime \prime} \mathrm{N}$ & $91^{\circ} 51^{\prime} 0.59^{\prime \prime E}$ \\
\hline CT 4 & Village Forest, Mawphlang & $25^{\circ} 27^{\prime} 11.77^{\prime \prime N} \mathrm{~N}$ & $91^{\circ} 45^{\prime} 15.96 " \mathrm{E}$ \\
\hline CT 5 & Botanical garden, Umiam, Shillong & $25^{\circ} 40^{\prime} 41.23^{\prime \prime N}$ & $91^{\circ} 54^{\prime} 26.48 " \mathrm{E}$ \\
\hline CT 6 & Forest Beat Office, Raid Laban, Shillong & $25^{\circ} 33^{\prime} 30.24^{\prime \prime} \mathrm{N}$ & $91^{\circ} 52^{\prime} 26.76 " \mathrm{E}$ \\
\hline
\end{tabular}


Table 4: Effect of physiological age of stem and IBA treatment on mean root number produced by cuttings from six candidate trees of Taxus baccata

\begin{tabular}{|c|c|c|c|c|c|c|c|c|}
\hline \multirow{2}{*}{$\begin{array}{l}\text { Physiol. } \\
\text { Age }\end{array}$} & \multirow{2}{*}{$\begin{array}{l}\text { IBA conc. } \\
\text { (ppm) }\end{array}$} & \multicolumn{6}{|c|}{ Candidate tree (CT) } & \multirow[t]{2}{*}{ Mean } \\
\hline & & CT 1 & CT 2 & CT 3 & CT 4 & CT 5 & CT 6 & \\
\hline \multirow{8}{*}{ 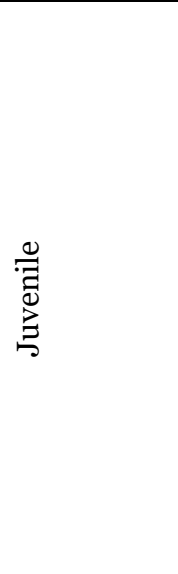 } & Control & $\begin{array}{l}2.00 \\
(1.48)\end{array}$ & $\begin{array}{l}3.61 \\
(2.03)\end{array}$ & $\begin{array}{l}0.67 \\
(1.00)\end{array}$ & $\begin{array}{l}0.33 \\
(0.88)\end{array}$ & $\begin{array}{l}0.67 \\
(1.00)\end{array}$ & $\begin{array}{l}0.00 \\
(0.71)\end{array}$ & $1.21(1.13)$ \\
\hline & 1000 & $\begin{array}{l}4.56 \\
(2.24)\end{array}$ & $\begin{array}{l}4.13 \\
(2.15)\end{array}$ & $2.33(1.66)$ & $\begin{array}{l}0.00 \\
(0.71)\end{array}$ & $\begin{array}{l}0.00 \\
(0.71)\end{array}$ & $1.17(1.14)$ & $\begin{array}{l}2.03 \\
(1.44)\end{array}$ \\
\hline & 2000 & $\begin{array}{l}3.33 \\
(1.95)\end{array}$ & $\begin{array}{l}4.17 \\
(2.16)\end{array}$ & $1.33(1.18)$ & $\begin{array}{l}0.00 \\
(0.71)\end{array}$ & $\begin{array}{l}0.00 \\
(0.71)\end{array}$ & $\begin{array}{l}0.67 \\
(1.00)\end{array}$ & $\begin{array}{l}1.58 \\
(1.52)\end{array}$ \\
\hline & 5000 & $\begin{array}{l}2.00 \\
(1.32)\end{array}$ & $\begin{array}{l}2.89 \\
(1.70)\end{array}$ & $3.17(1.90)$ & $\begin{array}{l}0.00 \\
(0.71)\end{array}$ & $\begin{array}{l}0.00 \\
(0.71)\end{array}$ & $\begin{array}{l}0.00 \\
(0.71)\end{array}$ & $\begin{array}{l}1.34 \\
(1.29)\end{array}$ \\
\hline & Mean & $\begin{array}{l}2.97 \\
(2.26)\end{array}$ & $\begin{array}{l}3.70 \\
(2.01)\end{array}$ & $\begin{array}{l}1.88 \\
(1.44))\end{array}$ & $\begin{array}{l}0.08 \\
(0.75)\end{array}$ & $\begin{array}{l}0.17 \\
(0.70))\end{array}$ & $0.46(0.89$ & $\begin{array}{l}1.54 \\
(1.34)\end{array}$ \\
\hline & Control & $\begin{array}{l}0.67 \\
(1.00)\end{array}$ & $\begin{array}{l}4.33 \\
(2.19)\end{array}$ & $\begin{array}{l}3.00 \\
(1.86)\end{array}$ & $\begin{array}{l}0.00 \\
(0.71)\end{array}$ & $1.00(1.10)$ & $\begin{array}{l}0.00 \\
(0.71)\end{array}$ & $\begin{array}{l}1.50 \\
(0.92)\end{array}$ \\
\hline & 1000 & $\begin{array}{l}2.33 \\
(1.57)\end{array}$ & $\begin{array}{l}4.00 \\
(2.12)\end{array}$ & $\begin{array}{l}4.94 \\
(2.33)\end{array}$ & $\begin{array}{l}0.00 \\
(0.71)\end{array}$ & $\begin{array}{l}0.00 \\
(0.71)\end{array}$ & $\begin{array}{l}0.67 \\
(1.00)\end{array}$ & $\begin{array}{l}1.99 \\
(1.05)\end{array}$ \\
\hline & 2000 & $\begin{array}{l}4.33 \\
(2.20)\end{array}$ & $\begin{array}{l}5.72 \\
(2.49)\end{array}$ & $\begin{array}{l}5.06 \\
(2.35)\end{array}$ & $\begin{array}{l}0.00 \\
(0.71)\end{array}$ & $\begin{array}{l}0.67 \\
(1.00)\end{array}$ & $\begin{array}{l}0.00 \\
(0.71)\end{array}$ & $2.63(1.11)$ \\
\hline \multirow{3}{*}{ Mean of CT } & 5000 & $1.67(1.25)$ & $\begin{array}{l}5.42 \\
(2.42)\end{array}$ & $\begin{array}{l}8.03 \\
(2.88)\end{array}$ & $\begin{array}{l}0.00 \\
(0.71)\end{array}$ & $\begin{array}{l}0.00 \\
(0.71)\end{array}$ & $\begin{array}{l}0.00 \\
(0.71)\end{array}$ & $\begin{array}{l}2.52 \\
(1.00)\end{array}$ \\
\hline & Mean & $2.16(1.51)$ & $\begin{array}{l}3.53 \\
(2.31)\end{array}$ & $3.16(2.36)$ & $\begin{array}{l}0.00 \\
(0.71)\end{array}$ & $0.52(0.8)$ & $\begin{array}{l}0.50 \\
(0.70)\end{array}$ & $\begin{array}{l}1.70 \\
(1.02)\end{array}$ \\
\hline & & $\begin{array}{l}2.57 \\
(1.88)\end{array}$ & $\begin{array}{l}3.62 \\
(2.16)\end{array}$ & $\begin{array}{l}2.52 \\
(1.90)\end{array}$ & $\begin{array}{l}0.04 \\
(0.73)\end{array}$ & $\begin{array}{l}0.35 \\
(0.75)\end{array}$ & $\begin{array}{l}0.17 \\
(0.48)\end{array}$ & \\
\hline \multicolumn{2}{|c|}{ Mean of IBA conc. } & & Control & 1000 & 2000 & 5000 & & \\
\hline LSD@5\% & \multicolumn{8}{|c|}{$\begin{array}{l}\text { CT }=0.75 \text {, Physiological age }=0.43 \text {, IBA conc. }=\text { NS CT } x \text { Physiol. Age }=0.09, \text { CT } x \text { IBA conc. }=\text { NS, } \\
\text { Physiol. Age } x \text { IBA conc. }=\text { NS, CT } x \text { Physiol. Age } x \text { IBA conc. }=\text { NS. }\end{array}$} \\
\hline
\end{tabular}

fig. in parenthesis are mean of square root transformed values of replicate.

Table 5: Effect of physiological age of stem and IBA treatment on mean root length (cm) of cuttings from six candidate trees of Taxus baccata

\begin{tabular}{|c|c|c|c|c|c|c|c|c|}
\hline \multirow[t]{2}{*}{ Physiol. Age } & \multirow[t]{2}{*}{ IBA conc. $(\mathrm{ppm})$} & \multicolumn{6}{|c|}{ Candidate tree (CT) } & \multirow[t]{2}{*}{ Mean } \\
\hline & & CT 1 & CT 2 & CT 3 & CT 4 & CT 5 & CT 6 & \\
\hline \multirow{7}{*}{$\begin{array}{l}\stackrel{0}{\vec{\Xi}} \\
\stackrel{\Xi}{\Xi} \\
.\end{array}$} & Control & 0.85 & 2.27 & 0.47 & 0.17 & 0.23 & 0.00 & 0.66 \\
\hline & 1000 & 2.76 & 2.87 & 1.32 & 0.00 & 0.00 & 0.64 & 1.27 \\
\hline & 2000 & 2.64 & 2.25 & 0.67 & 0.00 & 0.00 & 0.68 & 1.04 \\
\hline & 5000 & 1.00 & 1.79 & 2.05 & 0.00 & 0.00 & 0.00 & 0.81 \\
\hline & Mean & 1.81 & 2.30 & 1.13 & 0.04 & 0.06 & 0.33 & 0.94 \\
\hline & Control & 0.77 & 1.53 & 2.30 & 0.00 & 0.48 & 0.00 & 0.85 \\
\hline & 1000 & 1.27 & 2.63 & 3.53 & 0.00 & 0.00 & 0.67 & 1.35 \\
\hline \multirow{3}{*}{$\underset{\Xi}{\stackrel{\Xi}{\Xi}}$} & 2000 & 2.00 & 3.02 & 3.06 & 0.00 & 0.62 & 0.00 & 1.45 \\
\hline & 5000 & 0.43 & 3.04 & 2.66 & 0.00 & 0.00 & 0.00 & 1.02 \\
\hline & Mean & 1.12 & 2.56 & 2.89 & 0.00 & 0.28 & 0.17 & 1.17 \\
\hline \multicolumn{2}{|l|}{ Mean of CT } & 1.47 & 2.43 & 2.01 & 0.02 & 0.17 & 0.25 & \\
\hline \multirow{2}{*}{\multicolumn{2}{|c|}{ Mean of IBA conc. }} & & Control & 1000 & 2000 & 5000 & & \\
\hline & & & 2.01 & 1.54 & 1.51 & 1.38 & & \\
\hline \multicolumn{9}{|l|}{ LSD @ 5\% } \\
\hline
\end{tabular}




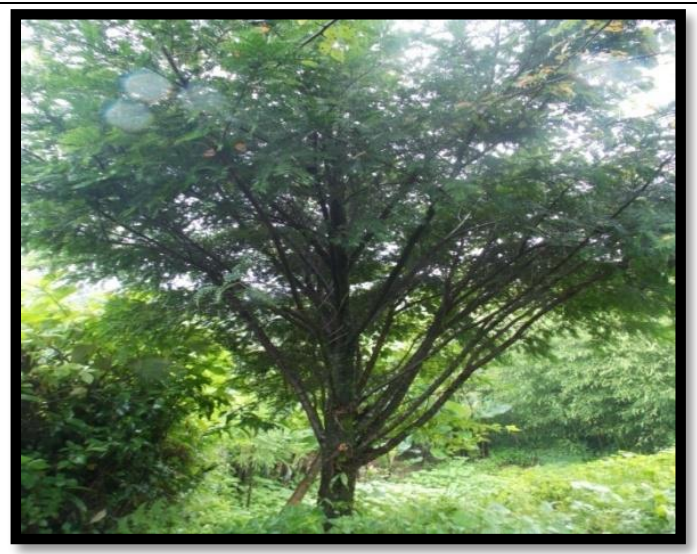

$\mathbf{a}$
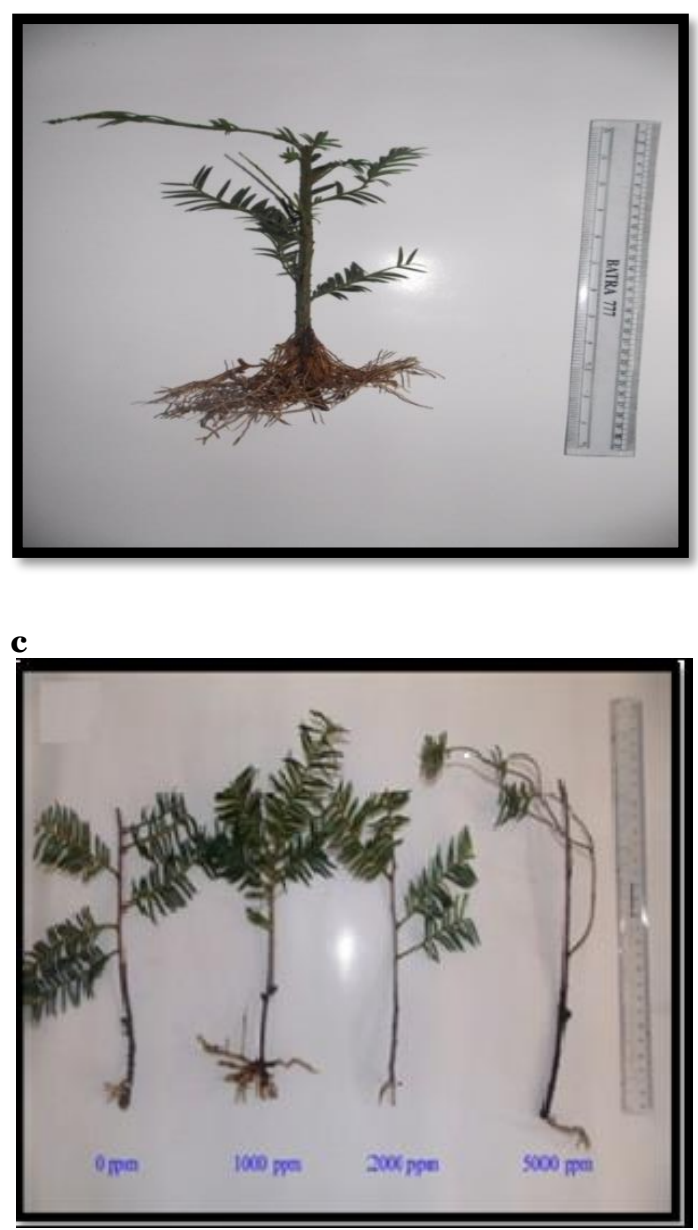

e

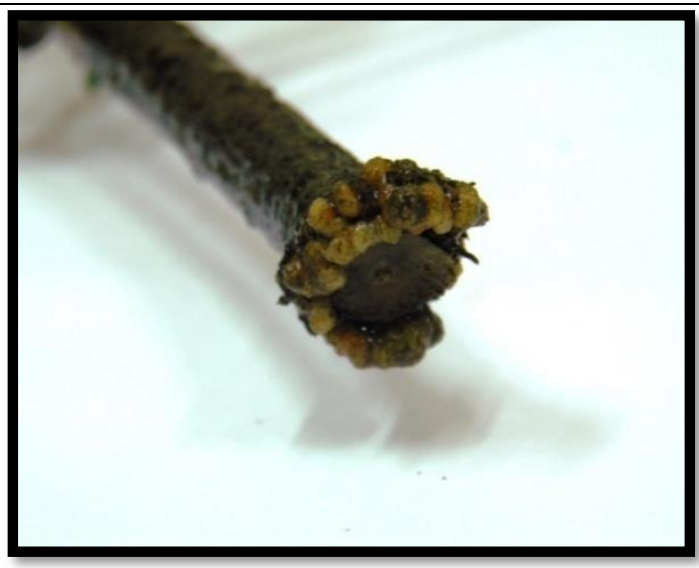

b

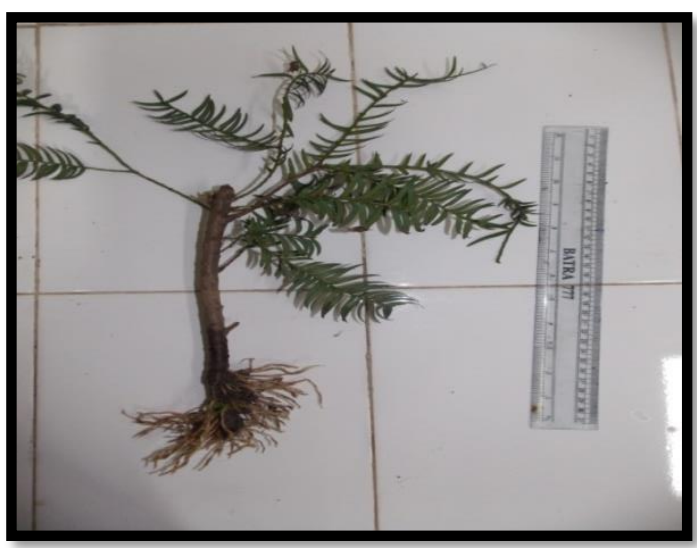

d

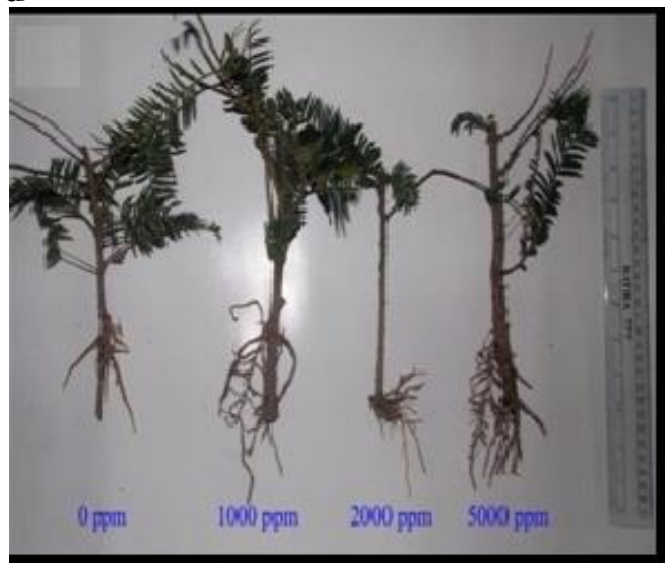

$\mathbf{f}$

Fig. 1: Propagation of Taxus baccata $\mathrm{L}$. by branch cutting (a) A candidate tree of Taxus baccata; (b) Callused formation in mature cutting from CT 3; (c) Vigorous rooting of juvenile cuttings obtained from CT 2; (d) Vigorous rooting of mature cuttings obtained from CT 2. (e) Rooting of IBA treated juvenile cuttings of Taxus baccata; (f) Rooting of IBA treated mature cuttings of Taxus baccata

\section{REFERENCES}

1. Lanker U, Malik AR, Gupta NK, Butola JS. Natural regeneration status of the endangered medicinal plant Taxus baccata Hook. F. Syn. T. Wallichiana, in northwest Himalaya. International Journal of Biodiversity Science, Ecosystem Services and Management. 2010;6 (1-2): 20-27.
2. Purohit A, Maikhuri RK, Rao KS, Nautiyal S. Impact of bark removal on survival of Taxus bacatta L. (Himalayan yew) in Nanda Devi Biosphere Reserve, Garhwal Himalaya, India. Current Science. 2001;81:586-590.

3. Anonymous. Taxon Data Sheet-50. Conservation Assessment and Management Plan Workshop, Pokhara, Nepal; 2001. 
4. Adhikari P., Pandey A. Taxus wallichiana zucc. (Himalayan Yew) in Antimicrobial Perspective. Advances in Biotechnology and Microbiolog. 2017;5 (4): 1-5.

5. Ge J, Ping W, Zhou D. Characterization of a New Species of Taxol-producing Fungus. Nature and Science. 2004;2:85-88.

6. Mangathayaru K. World wide Trade in Herbal product. In: Pharmacognosy: An Indian Perspective (eds). Dorling Kindersley (India) Pvt Limited, Pearson Edn.; 2013. p. 93.

7. Anonymous. Medicinal plants significant trade study. CITES project (S 109). India country report (unpublished report), Traffic India, New Delhi, India; 1998. p. 103.

8. Nicholson R, Munn DX. Observation on the propagation of Taxus globosa Schltdl. Boletin Dela Sociedad Botanica Mexicana. 2003;72:129-130.

9. Zarek MA. Practical method for overcoming the dormancy of Taxus baccata isolated embryos under in vitro conditions. In vitro Cellular and Developmental Biology-Plant. 2007;43:623-630.

10. Schneck V. Studies on influence of clone on rooting ability and rooting quality in the propagation of cuttings from 40-to 350-year-old Taxus baccata L. ortets. Silvae Genetica. 1996;45:246-249.

11. Fordham AJ, Sparker LJ. Propagation Manual of Selected Gymnosperms. Arnoldia 1977;p. 26.

12. Khali RP, Sharma AK. Effect of phytohormones on propagation of Himalayan Yew (Taxus Baccata L.) through stem cuttings, Indian Forester 2003;129:289294.

13. Aslam M, Rather MS. Macro-propagation of Taxus baccata Linn: a Novel Method for Conserving A Critically Endangered Medicinal Plant. Indian Forester. 2008;134 (8): 1058-1063.

14. Kaul K. Variation in rooting behavior of stem cuttings in relation to their origin in Taxus wallichiana Zucc. New Forests. 2008;36:217-224.

15. Anjum Q, Sharma LK, Ganie SA, Rather MM, Rather HA. Effect of auxins on macropropagation of Taxus baccata linn. through stem cuttings. Indian Forester. 2011;137 (12): 1382-1385.

16. Newton AC, Muthoka PN, Dick JM. The influence of leaf area on the rooting physiology of leafy stem cuttings of Terminalia spinosa Engl. Trees 1992;6:210-215.

17. Wojtusik T, Boyd MT, Felker P. Effect of different media on vegetative propagation of Prosopis juliflora under solar powered mist. Forest Ecology and Management. 1994;67:267-271.

18. Aminah H, Dick JMcP, Leakey RRB, Grace J, Smith RI. 1995. Effect of indole butyric acid (IBA) on stem cuttings of Shorea leprosula. Forest Ecology and Management. 1995;72:199-206.

19. Hartman HT, Kester DE, Davies FT, Geneve RL. Principles of Propagation by Cuttings. In: Hartmann HT, Kester DE, Davies, FT Geneve RL. (eds.) Plant propagation principle and practices. Prentice-Hall of India Private Limited, New Delhi; 2009. p. 318-320.

20. Trewavas AJ and Cleland RE. Is plant development regulated by changes in concentration of growth substance or by changes in the sensitivity to growth substance? Trends in Biochemical Sciences. 1983;8:354357.

21. Hoshmand A. R. Experimental Research Design and Analysis, CRC Press, Inc., United State of America. 1994.

22. Leakey RRB, Chapman VR, Longman KA. Physiological studies for tropical tree improvement and conservation. Factors affecting root initiation in cuttings of Triplochiton Scleroxylon K. Schum., Forest Ecol Manage 1982;4:53-66.

23. Dick JMcP, Bisset H, Mcbeath C. Provenance variation in rooting ability of Calliandra calothyrsus. Forest Ecology and Management. 1996;87:175-184.

24. Husen A. Clonal propagation of Dalbergia sissoo Roxb. by softwood nodal cuttings: effects of genotypes, application of IBA and position of cuttings on shoots. Silvae Genetica 2004;53 (2): 50-55.

25. Husen A. Clonal propagation of Teak (Tectona grandis) by using moderately hard stem cuttings: Effects of genotypes (FG1 and FG11 clones) and IBA treatment. Advances in Forestry Letters. 2013;2 (2) 14:19.

26. Ahuja MR, Libby WJ. In: Strategies for clonal forestry with poplars, aspens and willows. Clonal Forestry II. Springer-Verlag. Berlin Heidelberg, Germany; 1993. p. 97.

27. Moe R, Andersen AS. Stock plant environment and subseqeunt adventitious rooting. In: Davis TD Haissig, BE, Sankhla N. (eds). Adventitious root formation in cuttings. Advances in plant sciences, Volume 2. Dioscorides Press; Portland, Oregan; 1988.

28. Puri S, Swamy SL. Geographical variation in rooting ability of stem cuttings of Azadirachta indica and Dalbergia sissoo. Genetic Resource and Crop Evolution. 1999;46 (1): 29-36.

29. Amri E, Lyaruu HVM, Nyomora AS, Kanyeka, ZL. Vegetative propagation of African blackwood (Dalbergia melanoxylon Guill. and Perr.): effects of age of donor plant, IBA treatment and cutting position on rooting ability of stem cuttings. New Forests. 2010;39 (2): 183-194.

30. Husen A, Pal M. Variation in shoot anatomy and rooting behaviour of stem cutting in relation to age of donor plants in teak (Tectona grandis Linn. F). New Forests. 2006;31:57-73.

31. Opuni-Frimpong E, Karnosky DF, Storer AJ, Cobbinah JR. Key roles of leaves, stockplant age, and auxin concentration in vegetative propagation of two African mahoganies: Khaya anthotheca Welw. and Khaya ivorensis A. Chev. New Forests. 2008;36:115-123.

32. Das S, Jha LK. Effect of Wounding and Plant Growth Regulators (IBA and NAA) on root proliferation of Taxus wallichiana shoot cuttings. Research Journal of Agriculture and Forestry Sciences. 2014;2 (12): 8-14

33. Purnachandra GG, Dhananjaya MV, Kumar R. Effect of Indole Butyric Acid (IBA) On Rooting of Different Carnation (Dianthus caryophyllus L.) Genotypes. International Journal of Pure and Applied Science. 2017;5 (2): 1075-1080. 